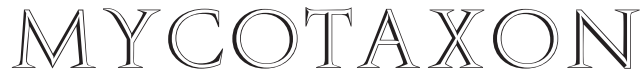

Volume 123, pp. 467-472

http://dx.doi.org/10.5248/123.467

January-March 2013

\title{
A new species of Cantharomyces (Laboulbeniales, Ascomycota) from the Netherlands
}

\section{Haelewaters ${ }^{1} \&$ A. De Kesel ${ }^{2}$}

${ }^{1}$ Department of Organismic and Evolutionary Biology, Harvard University

22 Divinity Avenue, Cambridge, Massachusetts 02138, U.S.A.

${ }^{2}$ National Botanic Garden of Belgium, Domein van Bouchout, 1860 Meise, Belgium

CORRESPONDENCE TO: ${ }^{1}$ dhaelewaters@fas.harvard.edu \& ${ }^{2} a d k @ b r . f g o v . b e$

Aвstract - This paper describes and illustrates Cantharomyces elongatus sp. nov., a parasitic fungus from Syntomium aeneum (Staphylinidae, Oxytelinae, Euphaniini). Syntomium is a new host genus for Cantharomyces. Comments on its position among related taxa are given.

KEY WORDS - insect-associated fungi, morphology, taxonomy

\section{Introduction}

Laboulbeniales are obligate ectoparasitic ascomycetes that live associated with arthropods, mostly insects. At present the order comprises about 2050 species in 140 genera (Rossi \& Santamaría 2012). Systematic and taxonomic contributions are available for several countries in western Europe and North America.

The genus Cantharomyces Thaxt. includes 28 species (Tavares 1985, Huldén 1983, Majewski 1990, Rossi \& Santamaría 2000), characterized by a receptacle consisting of three superposed cells, a compound antheridium subtending a simple or variably branched primary appendage, and a perithecium having four to five cells in each vertical row of outer wall cells (Thaxter 1931, Majewski 1994). Detailed information on Cantharomyces and its morphology and position among other Laboulbeniales is given in Thaxter (1890, 1896, 1908, 1931), Tavares (1985), Majewski (1990, 1994), and Santamaría (2003).

The host range of Laboulbeniales on Staphylinidae and other Coleoptera has been studied by Frank (1982), who listed 17 Cantharomyces species. In addition to Staphylinidae, Cantharomyces species have been reported from Dryopidae, Limnichidae, and Hydrophilidae (Tavares 1985). Based on recent taxonomic insights in Staphylinidae from Newton \& Thayer (2005) and Bouchard et al. (2011), four tribes of the Staphylinidae are host to Cantharomyces: Blediini 
and Oxyteliini (subfam. Oxytelinae), and Aleocharini and Oxypodini (subfam. Aleocharinae) (Thaxter 1890, 1896, 1908, 1931, Sugiyama 1973, Frank 1982, Huldén 1983, Tavares 1985, Majewski 1990, 1994, Rossi \& Santamaría 2000, Santamaría 2003).

This paper presents a new species of Cantharomyces, collected from a staphylinid beetle belonging to a fifth and so far unreported host tribe.

\section{Materials \& methods}

The host was found by sifting soil from an ash forest on clay. Infected material was dried, pinned, and identified by O. Vorst (using Lohse 1964). Screening for infection and removal of thalli was done at $50 \times$ magnification. Thalli were transferred with insect pin 0 and embedded in Amann solution (Benjamin 1971). Cover slips were ringed with transparent nail varnish. Both insect specimen and the examined microscope slides are deposited at the National Herbarium of Belgium (BR). Drawings and measurements were made using an Olympus BX51 light microscope with drawing tube, digital camera and AnalySIS Five imaging software (Soft Imaging System GmbH). Differences in the proportions of basal cell and suprabasal cell were analyzed using the ratios $\mathrm{R}_{\mathrm{L}}=$ length basal cell / length suprabasal cell and $\mathrm{R}_{\mathrm{w}}=$ width basal cell / width suprabasal cell. Average ratios are given for adult thalli, including minimum and maximum values in parenthesis.

Host taxonomy follows Newton \& Thayer (2005) and Bouchard et al. (2011).

\section{Taxonomy}

Cantharomyces elongatus Haelew. \& De Kesel, sp. nov.

Plate 1

MycoBank MB 800871

Differs from Cantharomyces orientalis by its single long, strictly unbranched, straight primary appendage with the basal cell $>2.5 \times$ longer and wider than the suprabasal cell.

Type: The Netherlands, Prov. Gelderland, Rha, $52^{\circ} 02.9^{\prime} \mathrm{N} 6^{\circ} 08.5^{\prime} \mathrm{E}$, on Syntomium aeneum (Müller, 1821) (Coleoptera, Staphylinidae, Oxytelinae, Euphaniini), 13 Oct 2001, leg. O. Vorst, slides Haelewaters 69a (holotype, 2 mature and 4 immature thalli, found on left elytron and abdominal tergites, BR MYCO 173753-26), Haelewaters 69b (isotype, 1 mature and 2 immature thalli found on elytra, BR MYCO 173752-25), and Haelewaters 69c (isotype, 2 mature and 2 immature thalli found on elytra, BR MYCO 173751-24).

ЕтумоLоgy: from the Latin adjective elongatus = elongate, referring to the long, unbranched primary appendage.

Thallus 145-175 $\mu \mathrm{m}$ long from foot to perithecial apex. Receptacle 50-60 $\mu \mathrm{m}$ long, cell I obtriangular, 22-30 $\mu \mathrm{m}$ long, cell II and cell III with similar shape, slightly pigmented, not blackened, broader than long, cell III somewhat longer than cell II. Primary APPendage composed of a basal cell, a small

Plate 1. Cantharomyces elongatus from Syntomium aeneum. A. Mature thallus from elytrum (holotype Haelewaters 69a). B-D. Immature thalli with perithecial primordium (holotype slide Haelewaters 69a). E. Immature thallus (isotype slide Haelewaters 69b). F. Submature thallus (isotype slide Haelewaters 69c). Scale bar $=50 \mu \mathrm{m}$. 
Cantharomyces elongatus sp. nov. (Netherlands) ... 469

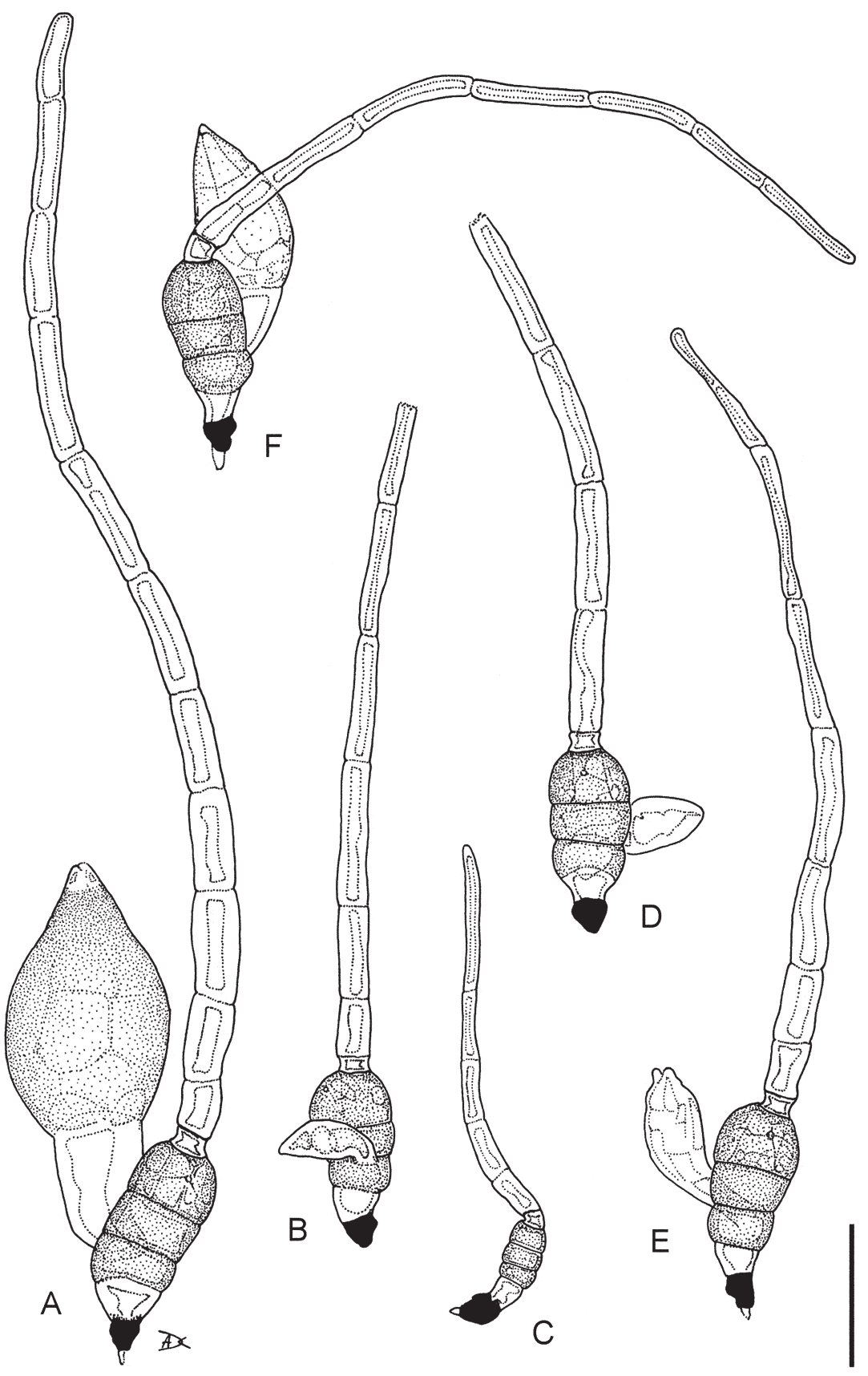


suprabasal cell and a series of elongate cells. Basal cell of primary appendage in the same axis as cell II and III, apically convex, slightly more pigmented than or concolorous with cells II and III, $23 \times 30 \mu$ m (length $\times$ width), basal septum with cell III straight. Suprabasal cell relatively flattened and small $\left[\mathrm{R}_{\mathrm{L}}=\right.$ $\left.2.88(2,77-3,17), \mathrm{R}_{\mathrm{w}}=2.81(2,58-2,96)\right], 6.5-10 \mu \mathrm{m}$ long, trapezoidal, slightly constricted, supporting a straight, 300-415 $\mu \mathrm{m}$ long unbranched series of 7-11 hyaline, thick-walled, elongate cells of $25-40 \mu \mathrm{m}$ each. ANTHERIDIUm located around a central core in the basal cell of primary appendage, with subapical opening on the latter's posterior side. Perithecium 72-96 $\times 40-57 \mu \mathrm{m}$, ovoid, symmetric, widest in the middle, tapering upwards, moderately pigmented; apex pointed, hyaline, poorly differentiated. Cell VI born laterally on cell II, 41-47 × 22-30 $\mu \mathrm{m}$, hyaline. Ascospores not seen.

Additional specimens examined: THE NETHERLANDS, Prov. Utrecht, Utrecht (Amelisweerd), 52 $04^{\prime} \mathrm{N} 5^{\circ} 09^{\prime} \mathrm{E}$, on Syntomium aeneum, $11 \mathrm{Nov} 1990$, leg. O. Vorst, slides Haelewaters 145a (1 damaged thallus from right elytron, BR MYCO 173750-23) and Haelewaters 145b (3 immature thalli found on prosternum, BR MYCO 173749-22).

\section{Discussion}

Cantharomyces elongatus is easily recognized by its very long and unbranched primary appendage with a relatively large basal cell and small trapezoidal suprabasal cell. Most of the time, even in a dried state, this long structure is found undamaged, indicating its robustness. In many genera of Laboulbeniales damaged appendages are known to regenerate in an erratic or at least atypical way. Among all examined specimens of C. elongatus we found several thalli with a normally regenerated, i.e. unbranched, appendage. Atypical regeneration of the appendage may be infrequent in this taxon since we found only one specimen with a bifurcate regenerated appendage (on its fourth appendage cell). Whenever a branched or aberrant appendage is seen in this taxon, one should look carefully for traces of damage to the appendage.

Cantharomyces elongatus was found on the pronotum, elytra, and abdominal tergites and does not seem to be morphologically variable on these different regions.

Cantharomyces elongatus is related to C. orientalis Speg., a very variable species having a primary appendage that is ramified above its suprabasal cell. Occasionally, however, C. orientalis bears a more or less short, unbranched appendage. In such cases, $C$. orientalis can still be easily distinguished from C. elongatus by its proportionally longer and wider suprabasal cell. In C. elongatus the basal cell is at least $2.5 \times$ longer and $2.5 \times$ wider than the suprabasal cell. Based on data from Belgian material and illustrations in Santamaría 2003 and Majewski 1994, this proportion is significantly smaller for C. orientalis, $\mathrm{R}_{\mathrm{L}}=$ $1.33(0.85-1.96)$ and $\mathrm{R}_{\mathrm{W}}=1.24(0.95-2.16)$. The combination of the appendage 
characteristics of length, branching, and relative height of the suprabasal cell should be enough to separate C. orientalis from C. elongatus.

Moreover, although $C$. elongatus and C. orientalis parasitize staphylinids from the same subfamily (Oxytelinae), they infect hosts belonging to different tribes: C. elongatus infects hosts of tribe Euphaniini and C. orientalis hosts of tribe Oxytelini.

Cantharomyces robustus T. Majewski shows many differences from C. elongatus: the blackening on the dorsal side of cell II, the ramified, shorter appendage, the inflated and rounded basal cell of the appendage (with antheridium), as well as large perithecial basal cells.

The new species is easily separated from the Cantharomyces species with an unbranched primary appendage: C. bordei F. Picard, C. denigratus Thaxt., and C. italicus Speg., based on the extreme length and construction of its primary appendage. Cantharomyces bordei has an unbranched, but short primary appendage. Furthermore, it is reported from Limnichus spp. (Coleoptera, Limnichidae) and exhibits a very short and constricted cell VI as well as a relatively massive perithecium (124-130 $\mu$ m long, Santamaría 2003). Cantharomyces denigratus and C. elongatus seem to share a similar organization of the antheridium (see Fig. 18a and d in Santamaría 2003). Cantharomyces denigratus, however, has a deeply pigmented receptacle. Cantharomyces italicus has a relatively long primary appendage but its antheridium is different, i.e. lens-shaped, small and laterally positioned within a more elongate basal cell of the primary appendage.

Cantharomyces numidicus Maire, as well as the very similar Cantharomyces japonicus K. Sugiy., differ in having a relatively large antheridial segment and a dissimilar arrangement of its primary appendage's basal cell (Thaxter 1931, Santamaría 2003).

Cantharomyces elongatus parasitizes Syntomium aeneum, extending the known host range of Cantharomyces to the staphylinid tribe Euphaniini (subfam. Oxytelinae).

\section{Acknowledgments}

The authors are indebted to Dutch entomologist Oscar Vorst for putting the host specimen and its identity at our disposal. Thanks are also due to Sergi Santamaría and Donald H. Pfister for reviewing the manuscript. We wish to express our gratitude to Cyrille Gerstmans for technical support and the Uyttenboogaart-Eliasen Foundation for financing part of this research.

\section{Literature cited}

Benjamin RK. 1971. Introduction and supplement to Roland Thaxter's Contribution towards a Monograph of the Laboulbeniaceae. Bibliotheca Mycologica 80: 1-155. 
Bouchard P, Bousquet Y, Davies AE, Alonso-Zarazaga MA, Lawrence JF, Lyal CHC, Newton AF, Reid CAM, Schmitt M, Ślipiński SA, Smith ABT. 2011. Family-group names in Coleoptera (Insecta). Zookeys 88: 1-972. http://dx.doi.org/10.3897/zookeys.88.807

Frank JH. 1982. The parasites of the Staphylinidae (Coleoptera). Bulletin Florida Agricultural Experiment Stations 824(1-7): 1-118.

Huldén L. 1983. Laboulbeniales (Ascomycetes) of Finland and adjacent parts of the U.S.S.R. Karstenia 23(2): 31-136.

Lohse GA. 1964. Staphylinidae I (Micropeplinae bis Tachyporinae). Die Käfer Mitteleuropas, Band 4. $264 \mathrm{p}$.

Majewski T. 1990. Rare and new Laboulbeniales from Poland. X. Acta Mycologica 23(2): 97-108.

Majewski T. 1994. The Laboulbeniales of Poland. Polish Botanical Studies 7: 1-466.

Newton AF, Thayer MK. 2005. Catalog of austral species of Staphylinidae and other Staphylinoidea [online]. Chicago: Field Museum of Natural History.

http://www.fieldmuseum.org/peet_staph/db_1b.html [accessed June 16 2012]

Rossi W, Santamaría S. 2000. New Laboulbeniales parasitic on Staphylinidae. Mycologia 92(4): 786-791. http://dx.doi.org/10.2307/3761436

Rossi W, Santamaría S. 2012. Rodaucea, a new genus of the Laboulbeniales. Mycologia 104(3): 785-788. http://dx.doi.org/10.3852/11-337

Santamaría S. 2003. Laboulbeniales, II. Acompsomyces-Ilyomyces. Flora Mycologica Iberica 5: $1-344$.

Sugiyama K. 1973. Species and genera of the Laboulbeniales (Ascomycetes) in Japan. Tokyo, Academia Scientific Book Inc.

Tavares II. 1985. Laboulbeniales (Fungi, Ascomycetes). Mycologia Memoir 9: 1-627.

Thaxter R. 1890. On some North American species of Laboulbeniales. Proceedings of the American Academy of Arts and Sciences 27: 29-45. http://dx.doi.org/10.2307/20020464

Thaxter R. 1896. Contribution towards a monograph of the Laboulbeniaceae. Memoirs of the American Academy of Arts and Sciences 12: 187-429.

Thaxter R. 1908. Contribution towards a monograph of the Laboulbeniaceae. Part II. Memoirs of the American Academy of Arts and Sciences 13: 217-469. http://dx.doi.org/10.2307/25058090

Thaxter R. 1931. Contributions towards a monograph of the Laboulbeniaceae. Part V. Memoirs of the American Academy of Arts and Sciences 16: 1-435. http://dx.doi.org/10.2307/25058136 